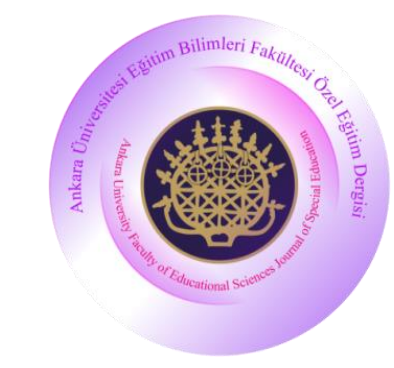

\section{Ankara University Faculty of Educational Sciences Journal of Special Education}

Year: 2020, Volume: 21, No: 3, Page No: 427-450

doi: 10.21565/ozelegitimdergisi.597433

\title{
The Effectiveness of Progressive Time Delay on Teaching Pedestrian Skill to Individuals with Intellectual Disability
}

\author{
Kübra Ăgrı \\ Anadolu Üniversitesi
}

\author{
Emine Sema Batu ${ }^{(D * * *}$ \\ Anadolu Üniversitesi
}

\begin{abstract}
The purpose of the study was to examine the effectiveness of progressive time delay teaching method on teaching a pedestrian skill to individuals with intellectual disabilities. The study was conducted with three participants with mild intellectual disabilities who were 10-11 years old. Multiple probe design across participants was used in the study. The results of the study revealed that the participants of the study acquired the targeted pedestrian skill, the first participant maintained the acquired skill one, three and five weeks after the implementation was completed whereas the third participant maintained the skill one, two and four weeks after the implementation was completed. Besides, all participants generalized the skill which they acquired on a simulation material to a real environment. Social validity results of the study revealed that the parents of the participants and the policeman who took part in the generalization session had positive opinions about the study.
\end{abstract}

Keywords: Intellectual disability, pedestrian skill, safety skills, progressive time delay, evidence-based practices.

\section{Recommended Citation}

Ağrı, K., \& Batu, E. S. (2020). The effectiveness of progressive time delay on teaching pedestrian skill to individuals with intellectual disability. Ankara University Faculty of Educational Sciences Journal of Special Education, 21(3), 427-450. doi: 10.21565/ozelegitimdergisi.597433

\footnotetext{
${ }^{*}$ This article is based on the master thesis written by Kübra Ağr1 under the supervision of Prof. Dr. Emine Sema Batu. It was also presented as an oral presentation in the $2^{\text {nd }}$ International Contemporary Educational Research Congress in Muğla/Turkey in 2017.

${ }^{* *}$ Corresponding Author: Res. Assist., E-mail: kubraagri@ anadolu.edu.tr, https://orcid.org/0000-0003-1538-197X

***Prof., E-mail: esbatu@ anadolu.edu.tr, https://orcid.org/0000-0003-0770-5145
} 
Independent living skills include house life, vocational skills and leisure skills. They help individuals take part in the community actively and acquire the choice making ability (Nosek, 1992; Stlington, Neubert, \& Clarck, 2010). When evaluated from the view of independent living skills of individuals with intellectual disability (ID), the most important limitation of those individuals is that they usually cannot take part in daily living activities independent from others (Jones et al., 1999). Daily living skills are the fundamentals of increasing independent living in the community (Ramdoss et al., 2012).

By teaching home and community living skills to individuals with intellectual disabilities, these individuals can join the daily routines within family and the community. Afterwards, they can gain independence and manage themselves for the adulthood (Bambara, Kroger, \& Bartholomew, 2014). However, looking at the teaching procedure and the target skills to be primarily taught to them, it can be seen that community living skills are not selected from these skills. Community living skills are taught as a result of the needs and preferences of the parents and individuals themselves in the settings they live (Dymond, 2012).

Although community living skills are taught in natural environments, some of these skills should also be taught in simulation settings (Test \& Spooner, 2005). The purpose of using simulation settings is to maintain the acquisition of some skills which are difficult or dangerous to teach within natural environments (McDonnell, Horner, \& Williams, 1984). If the simulation setting is prepared similar to the real environment and the responses can be arranged similar to the real ones, simulation settings can be effective (Browder, Snell, \& Wildonger, 1988).

There are some skills which help people reach independent living standards. Considering the safety conditions, teaching these skills especially to individuals with developmental disabilities in natural environments can be risky. Therefore, skills including buying goods and withdrawing money from ATM (Bates, Cuvo, Miner, \& Korabek, 2001; Cihak, Alberto, Taber-Doughty, \& Gama, 2006), home accidents, basic first aid skills, and asking for help from adults (Christensen, Lingugaris, Kraft, \& Fiechtl, 1996; Christensen, Marchand-Martella, Martella, Fiechtl, \& Chiristensen, 1993; Ergenekon, 2012), fire safety skills (Jones, Kazdin, \& Haney, 1981), padestrian skills (Batu, Ergenekon, Erbaş, \& Akmano ğlu, 2004; Branham, Collins, Schuster, \& Kleinert, 1999; Collins, Stinson, \& Land, 1993; Page, Iwata, \& Neef, 1976) were taught using simulation settings in the literature.

Safety skills include self-protection and the avoidance of verbal or non-verbal behaviors that may occur in daily life and harm the individual. (Clees \& Gast, 1994). Besides, personal safety skills are necessary while crossing the road, knowing what to do when forced by someone to do something or other conditions (Dixon, Bergstrom, Smith, \& Tarbox, 2010). Collins, Wolery and Gast (1992) grouped safety skills under six categories: In-home safety skills, community safety skills, protection from fire, first-aid skills, protection from strangers, and sexual abuse. Community safety skills require mobility and travelling skills. They can be defined as being mobile in the near environment or across districts (West, Witting, \& Barrett, 2012).

Teaching skills which require the individuals to be mobile is the prerequisite for crossing the road safely (Josman, Ben-Chaim, Friedrich, \& Weiss, 2008). From the perspective of children, one of the most important activities which require mobility of the children is pedestrian skills (Yeaton \& Bailey, 1978). One of the most frequently used pedestrian skills is approprately crossing the road where there is no traffic (Westling \& Fox, 2000). In order to teach crossing the road safely to children, one should teach the meanings of traffic signs, predicting the speed and distance of approaching cars, and predicting his/her own speed needed for crossing the road before the approaching car arrives (Barton \& Schwebel, 2007). Different junctions should be used. The skills should be acquired $100 \%$ correctly while teaching this skill (Westling \& Fox, 2000).

There are studies in which crossing road skills were taught in simulation settings (Hawkins, 2016; Batu, et al., 2004; Branham et al., 1999; Collins, et al., 1993; Page et al., 1976; Tohum Otizm Vakfi, 2013), in natural environments (Colozzi \& Polloway, 1984; Harriage, Blair, \& Miltenberger, 2016, Honsberger, 2015; Kelley, Test, \& Cooke, 2013; Mechling \& Seid, 2011; Yavuz, 2017). Also, visual reality was used in one study (Josman et al., 2008). The participants were between 7 and 26 years of age among these studies. As pedestrian skills are 
prerequisite for individuals with intellectual disabilities in terms of their attendance to the community living, pedestrian skills should be taught to individuals with intellectual disabilities as early as possible.

Teaching pedestrian skills to individuals with intellectual disabilities through different methods and settings is possible. In the present study, progressive time delay teaching method was utilized to teach a pedestrian skill which is one of the most important safety skills for individuals with intellectual disabilities. In the progressive time delay teaching method, prompts are delayed depending on a plan. Following the target stimuli, the person is provided time to respond independently. Thus, the method gives an opportunity to fade the prompt by means of time (Tekin-İftar \& Kircaali-İftar, 2012). Since the absence of pedestrian skills might be dangerous for these individuals, fading prompts by means of time will deliver benefit in terms of teaching these skills. Previous studies taught various skills through progressive time delay to individuals with intellectual disabilities. In these studies; providing and not providing instructional feedback with two-dimensional symbols, words and images (Reichow \& Wolery, 2011), teaching visual reading skill (Casey, 2008), teaching kitchen goods naming (Kanbaş, 2002), teaching motor skills (Chen, Zhang, Lange, Miko, \& Joseph, 2001), decreasing problem behaviors (Heckaman, Alber, Hooper, \& Heward, 1998), teaching requesting skill (Leung, 1994), teaching the behavior of imitating peers in the arts class (Venn \& Wolery, 1992), teaching job naming (Wolery, Gast, Kirk, \& Schuster, 1988), teaching how to point to products (Bennet, Gast, Wolery, \& Schuster, 1986) were studied. Although there are many studies which aimed to teach different skills through progressive time delay, no studies targeting pedesterian skills were found in the literature. As the utilization of progressive time delay results in the generalization of the acquired skill by means of time, it paves the way for the individual to use the acquired safety skill in the community settings.

Progressive time delay teaching method leads to fading the prompt without making any difference within its type and intensity. Besides, the prompt provides the participant an opportunity to respond and generalize the skill without adhering to a strict time period (Tekin-İftar \& Kircaali-İftar, 2012). Following the acquisition of the pedestrian skills, individuals with intellectual disabilities can maintain their independence by taking part in the community actively without any need for additional support. Therefore, the purpose of the present study was to examine the effectiveness of progressive time delay on teaching a pedestrian skill to individuals with intellectual disability. The following research questions were addressed:

1. Was progressive time delay effective in teaching a pedestrian skill (first to look left, then to the right and again to the left and walk to the midway and stop there, and again look to the right where the cars come then to the left and again to the right and cross the pedestrian road) to individuals with intellectual disabilities?

2. Did individuals with intellectual disabilities maintain the acquired skill 1,2 , and 4 weeks after the training was completed?

3. Did individuals with intellectual disabilities generalize this skill to different settings and with different materials?

4. What were the opinions of the parents of the participants and the police officers who followed the research implementation procedure?

\section{Method}

\section{Participants}

The participants were the first author of the study, a student from the pilot study, students and their parents in the training procedure, and the police officer. The following prerequisite behaviors were considered in the identification of the participants: (a) being able to follow directions comprising of at least two words, (b) wait for the controlling prompt, (c) pay attention to a condition for at least 10 minutes, (d) distinguish between his/her right and left side, along with the condition of (e) not taking part in a systematic teaching procedure regarding the target skill, and (f) accepting to take part in the study. Besides, the participants did not have pedestrian skills in their 
repertoire. The assessment was conducted at Sezai Aksoy Traffic Training Park following the approval of the municipality. The training procedure was implemented with three students with intellectual disabilities.

Betül was an 11-year-old female with intellectual disability. She was a fourth-grade student in an inclusion classroom. She also attended to a special education and rehabilitation center two days a week. Betül did not have any physical challenges, so she was able to demonstrate all gross and fine motor skills. She could initiate and hold communication with unfamiliar people. Betül could follow two consecutive directions successfully. She was able to manage self-help skills independently, as well. She could follow rules in public transportation. She could read and write basic words, could recognize and name geometrical figures, basic concepts and could count from 1 to 20 rhythmically.

İbrahim was a 10-year-old boy with intellectual disability. He was attending to the fourth grade in an inclusive classroom and also to a special education and rehabilitation center twice a week. He did not have any gross and fine motor limitations. He could only express himself through utterances comprising of one word in terms of his expressive language ability. He could follow the given instructions. He could make eye contact when communicating with others. He had limitations in managing his self-help skills. He could not use public transportation independently, he had limitations in following the rules in some community settings. He could point to the object (named before) and tell the name (when asked). He could point to basic geometrical figures named.

Yavuz was an 11-year-old boy with intellectual disability. He was attending to the special education class in a regular primary school. He was taking special education courses at home for academic purposes. He was attending to a special education and rehabilitation center three days a week. He could display skills related to fine and gross motor activities. He could start and continue communication with others. He could manage basic selfhelp skills and daily living skills with partial prompts. Yavuz could follow some of the rules in the community life but could not use public transportation independently. He could show the object and colors in academic areas (named before) and tell the name (when asked). He could count up to 20.

Table 1

Participants of the Study and Their Characteristics

\begin{tabular}{lcc}
\hline Code name & Age & Diagnosis \\
\hline Betül & 11 & Mild intellectual disability \\
İbrahim & 10 & Mild intellectual disability \\
Yavuz & 11 & Mild intellectual disability \\
\hline
\end{tabular}

\section{Setting}

Baseline, full probe, training and maintenance sessions of the study were conducted at the simulation setting in the Faculty of Education based in Anadolu University. The simulation setting consisted of a two-way road with a central refuge, two pavements on each side of the road, two tow cars on the road, pedestrian stripes.

Generalization sessions were conducted on a road where traffic was not very busy with the official permission of the Traffic Implementation and Inspection Unit in Eskişehir, Turkey. In the generalization setting, there was a two-way road where there was a pavement in the middle and also on both sides of the road, a bus stop on one side of the road, little trees on the pavement in the middle, and pedestrian stripes.

The written consents of the parents of the participants in a real setting with the participation of a police officer were obtained. During generalization sessions, the trainer provided the target stimuli entitled "cross the road" and walked behind the participant while crossing the road. The traffic police officer controlled the traffic flow on the road and maintained the safety during the sessions.

\section{Materials}

Written Consent Form, Reinforcer Determination Form, Skill Analysis Form, a handy cam, two tow cars, pedestrian stripes, pavements, central refuge in the middle of the two way road, Data Recording Form, Inter- 
observers and Treatment Integrity Data Recording Forms, Social Validity Data Recording Forms for Parents, Teachers, and Police Officer were utilized in the present study.

\section{Design}

Multiple probe design across participants with probe conditions model was used in order to examine the effectiveness of progressive time delay teaching method on teaching a pedestrian skill to individuals with intellectual disability in the study. The effectiveness of the independent variable was examined on the participants through the current design (Tekin-İftar \& Kırcaali-İftar, 2012).

\section{Dependent and Independent Variables}

Dependent variable of the study was the correct response percentage of the pedestrian skill which is very essential for all individuals including those with intellectual disability in order to live independently in the community and take an active role in the community life. Percentage of correct responses were calculated depending on the Skill Analysis Form which was developed by the authors. Teaching sessions of the skill were conducted through a whole skill teaching approach. Correct responses were calculated by "number of correct responses/ total number of responses x 100" formula (Tekin-İftar \& Kircaali-İftar, 2012).

Independent variable of the study was progressive time delay teaching method. During the implementation of the progressive time delay teaching method, first session was conducted at 0-sec delay, and the rest of the training sessions were conducted with progressive time delays with pre-determined criteria $(2,4$, and 6 sec.).

\section{Procedure}

Implementation procedure of the study consisted of the pilot study, baseline, full probe, training, maintenance and generalization sessions. It took approximately two months in total. All sessions were recorded using a handy cam. All the sessions were conducted in one-to-one format by the first author.

Baseline sessions. Baseline sessions were conducted with the participants separately. They were realized until a constant data was secured in three consecutive sessions by using single opportunity method. During these sessions, the target stimulus was provided (... cross the street.) and the data was recorded with (-) at the step which the participant could not realize. Although the participant could not manage one of the steps, s/he was permitted to continue the behavior under the control of the researchers. The baseline data were collected without providing any prompts and reinforcers. Correct response percentage was calculated following the data collection.

Full probe sessions. After securing constant data with the first participant in the training sessions, full probe data were collected from all the participants. When three constant data were collected during the full probe sessions, training sessions were conducted with the second participant. After collecting three constant data from the second participant in the training sessions, full probe sessions were conducted with all participants again. When three constant data were collected during the full probe sessions, training sessions were conducted with the last participant. When the criterion was met by the third participant in the training sessions, full probe sessions were conducted with all the participants again and the procedure was completed. During the full probe sessions no reinforcers were provided to the participants. Correct response percentage was calculated regarding the data collected during the full probe sessions.

Training sessions. After getting constant data from the baseline sessions, training sessions were conducted with the first participant. Training procedure was employed in the simulation setting for teaching crossing the road via pedestrian stripes through progressive time delay teaching method. Training sessions were conducted at the simulation setting in the Faculty of Education based in Anadolu University. A training session was conducted twice a week during the weekdays and two training sessions were conducted on the weekend. 
Before the training sessions started, all materials were prepared and arrangements were made. Training sessions were conducted at 0 -sec delay and progressive time delay sessions (2, 4, and 6 sec.).

(a) 0 Sec time delay training sessions. The participants were asked to stay in the working area at the beginning of the sessions. After securing the attention of the participant on the study, s/he was told "... now we are going to cross the street. If you work good enough, you can ... (watch cartoon for the two participants, drive the tow cars for the last participant) at the end of the activity." They were also told "If you are ready, let's start." The participant's response was expected. Following this response, the training session started with the target stimulus "Cross the road." After the target stimulus; partial physical prompt, modeling and verbal prompt were provided as the controlling prompts. The participants were told in the following: "First we are waiting on the pavement and we are looking to the left where cars come and then to the right and again to the left." and the skill was realized. The participants waited three seconds as this was the required response interval to complete the step. Afterwards, the second skill was practised.

During the second skill, the trainer showed the cars to the participant and said: "The cars are far away, so we can cross the road now." The arm of each participant was held by the trainer physically and controlling prompt was used to cross the road. If the participant could not realize the step within three seconds, controlling prompt was provided and this step was realized by the participant.

The third step of the skill was "coming to the middle refuge and waiting". The participant was provided with the verbal prompt "yes, we have come and we are waiting here." Along with modeling and a physical prompt (holding the participant's arm). The fourth step of the skill analysis was to "look to the right where cars are coming, then look to the left and again to the right". The participants were provided with controlling prompts. They realized this step simultaneously with the trainer.

The fifth step of the skill analysis was "after being sure that the cars are far enough, crossing the road by using the pedestrian stripes". This step was realized after saying "look, the car is far away, so we can cross the road" and showing the pedestrian stripes and providing the controlling prompt. The last step of the skill analysis was "coming to the pavement and stopping on the pavement". These two skills were performed simultaneously. Therefore, they were considered in the same skill step. At the end of this step, the trainer praised the participant by saying "Our session is over, you've done great job. Thank you.".

(b) Progressive time delay training sessions. This part of the study started through securing the attention of the participant on the study and mentioning the reinforcer to the participant. The participant was given the target stimulus entitled "cross the road". All participants started to cross the road as soon as the target stimulus was provided. Since the target skill was dangerous, the first step of the target skill was realized at 0-sec delay condition. In this condition, after the target stimuli was provided in the first step, the trainer said "first we wait on the pavement and we look to the left where cars are coming, then to the right and then to left again". Since the participants stepped down the pavement, the trainer provided the controlling prompt by holding one of their arms and pointed to the left first, then to the right and then to the left again. Following the first step, the participants were praised verbally.

After this step, the participants waited to perform the second step of the skill analysis (after making sure that the cars do not arrive or are far away, they quickly cross the street using the pedestrian crossing) with a pause of two seconds. When the participant realized this step, s/he was praised verbally. If the participant performed the skill incorrectly or showed no response, at the end of two seconds, controlling prompt (showing the car, "the car is far away and" showing the pedestrian stripes "we can cross the road") was provided and his/her movement started by as he/she touched his/her arm within the response interval (three seconds). Following this step, it was passed on to the third step.

The third step of the analysis was "coming to the middle refuge and waiting there". If the participant come to the middle refuge and waited, s/he was praised verbally ("yes, we came and we are waiting now, well done"). 
If the participant performed incorrectly, which meant attempting to step down the pavement; the trainer provided the controlling prompt by holding his/her arm (partial physical prompt) and saying "we are waiting on the pavement" (verbal prompt and modeling). S/he was provided two seconds to perfom this step correctly ("looking to the right where cars are coming, then looking to the left and again to the right"). If the participant looked to the right first, s/he was praised verbally ("yes, we are looking to our right where cars are coming first, then to the left and again to the right, well done"). If the participant responded incorrectly or showed no response within two seconds, the trainer provided controlling prompts by saying "we are looking to our right first, where cars are coming, then we look to the left and again to the right" and helping the participant turn his head to the right. The participant was waited to respond within the response interval. Generally, all participants performed the skill simultaneously with the trainer. For the participant to perform the fifth step (after being sure that the cars were far enough, crossing the road by using the pedestrian stripes quickly) two seconds were given. When the participant realized the skill step correctly, s/he was praised by saying "yes, the cars were far enough, so we crossed the road, well done". When the participant did not perform the step correctly or s/he had no response, s/he was given the controlling prompt (his arm was touched slightly and the pedestrian road was shown and the following was told "the cars are far enough, we can cross the road"). When the participant performed the skill step within the response interval correctly, the last skill step ("coming to the pavement and stopping on the pavement") of the target skill was practised. Within this step, "coming to the pavement" and "stopping on the pavement" were realized simultaneously. When the participant performed the step correctly within the response interval, s/he was praised by saying "well done, we came to the pavement and stopped on it. Thank you for studying with me so good.".

All progressive time delay sessions were conducted with the same format by increasing the response interval after the participant performed the previous response interval within the predetermined criterion. Progressive time delay procedure was realized by conducting the training sessions with two seconds response interval until the participants met the $32 \%$ correct response criterion, four seconds response interval until the participants met the $64 \%$ correct response criterion, and six seconds response interval until the participants met the $100 \%$ correct response criterion.

Generalization sessions. Generalization sessions were conducted in order to examine if the participants could generalize the acquired skill of crossing the road into the natural environment or not. Since the target skill required maximum safety, post-test generalization sessions were carried out in a semi-structured environment. The post-test generalization sessions were conducted on a suburban street by the permission of Traffic Implementation and Inspection Unit in Eskişehir under the control of two traffic police officers.

These sessions were conducted similar to the baseline sessions; the target stimuli was presented and no reinforcers were provided. Single opportunity method was used during the sessions. The correct response percentage was calculated by dividing the number of correct responses to the number of total steps and multiplied by 100 .

Maintenance sessions. Except the first participant, maintenance sessions were conducted one, two and four weeks after the training sessions were completed. Due to high rates of problem behaviors, these sessions could not be realized with the second participant. Therefore, such data were collected only with the third participant one, two and four weeks after the completion of the training sessions. Since the first participant went to holiday with his family, his maintenance sessions were realized two, three and five weeks after completing the training sessions. These sessions were also conducted similar to the baseline sessions.

\section{Data Collection}

Three types of data were collected: Effectiveness, reliability, and social validity data.

Effectiveness data. These data were collected through the skill analysis forms during the baseline, full probe, training, maintenance and generalization sessions in order to determine the effectiveness of progressive time delay teaching method on teaching a pedestrian skill to individuals with developmental disability. Correct 
responses before the prompts were recorded as correct and others were recorded as incorrect responses. Correct response percentage of the collected data was calculated by "number of correct responses / total number of responses X 100" formula (Erbaş, 2012).

Reliability data. Treatment reliability and interobserver reliability data analysis were employed at the end of the study. Treatment reliability was analyzed by using "Observed trainer behavior / Planned trainer behaviors X 100” formula (Tekin-İftar \& Kircaali-İftar, 2012). Interobserver reliability data were analyzed by using "Number of agreements / Number of agreements + disagreements X 100 (Tekin-İftar \& Kircaali-İftar, 2012). $30 \%$ of each group of sessions were selected for calculating the reliability scores of the study randomly. Treatment reliability scores were $99 \%$ for Betül, $99 \%$ for Ibrahim, and 100\% for Betül whereas interobserver reliability scores were $85 \%$ for Betül, $100 \%$ for Ibrahim and $100 \%$ for Yavuz.

Table 2

Treatment Integrity Data of Baseline, Training, Full Probe, Maintenance, And Generalization Sessions Regarding the Target Pedestrian Skill

\begin{tabular}{lcccc}
\hline Participant & Baseline & Full probe & Training & Maintenance \\
\hline Betül & $100 \%$ & $93 \%$ & $100 \%$ & $100 \%$ \\
İbrahim & $100 \%$ & $100 \%$ & $97 \%$ & $100 \%$ \\
Yavuz & $100 \%$ & $100 \%$ & $100 \%$ & $100 \%$ \\
\hline
\end{tabular}

Table 3

Interobserver Reliability Data of Baseline, Training, Full Probe, Maintenance, And Generalization Sessions Regarding the Target Pedestrian Skill

\begin{tabular}{lccccccc}
\hline Participant & Baseline & $\begin{array}{c}\text { Full } \\
\text { probe }\end{array}$ & $\begin{array}{c}\text { Training } \\
0 \text { sec. }\end{array}$ & $\begin{array}{c}\text { Training } \\
2 \text { sec. }\end{array}$ & $\begin{array}{c}\text { Training } \\
4 \text { sec. }\end{array}$ & $\begin{array}{c}\text { Training } \\
6 \text { sec. }\end{array}$ & Maintenance \\
\hline Betül & $100 \%$ & $100 \%$ & $100 \%$ & $83 \%$ & $83 \%$ & $96 \%$ & $100 \%$ \\
İbrahim & $100 \%$ & $100 \%$ & $100 \%$ & $100 \%$ & $100 \%$ & $100 \%$ & $100 \%$ \\
Yavuz & $100 \%$ & $100 \%$ & $100 \%$ & $100 \%$ & $100 \%$ & $100 \%$ & $100 \%$ \\
\hline
\end{tabular}

Social validity data. Social validity data were collected in order to evaluate the opinions of parents and the police officer regarding the effectiveness of the study and importance of the target skill. Moving with this purpose, a social validity form for parents consisting of six yes/no questions and three open-ended questions and a social validity form for the police officer consisting of four yes/no questions and two open-ended questions were developed. Since only one of the police officers volunteered to provide information for the social validity data, only his responses were included in the study. Social validity data were collected via one-to-one interviews which were conducted by the first author with the parents of the participants and the police officer.

\section{Results} reported.

In this part of the study; effectiveness, maintenance, generalization and social validity results were

\section{Effectiveness Results}

The data of the participants regarding the instruction of a pedestrian skill to individuals with intellectual disability by progressive time delay can be seen in Figure 1 . Generalization data of the study can be seen in Figure 2 .

Betül's baseline, training, full probe, and maintenance data of crossing the road by using the pedestrian stripes Betül's baseline, training, full probe, and maintenance data of crossing the road by using the pedestrian stripes can be seen in Fig 1. Betül displayed a performance of $0 \%$ correct response in each of three baseline sessions consecutively. Apart from the baseline sessions, depending on the model, three full probe sessions were also conducted with Betül. The full probe sessions were conducted after the training sessions were completed. During 
the full probe sessions Betül performed with 100\% accuracy. Training sessions were completed with 12 sessions. During the first session, she performed with $16 \%$ accuracy for 0 -second response interval. During the 2 -second response interval sessions, 33\% correct responses in the second session, 33\% correct responses in the third session and $50 \%$ correct responses in the fourth session were recorded. During the 4 -second response interval sessions, $66 \%$ correct responses in the fifth, sixth and seventh sessions were recorded consecutively. During the 6-second response interval sessions, she performed with $66 \%$ accuracy in the eighth session, with $83 \%$ accuracy in the ninth session, and with $100 \%$ accuracy in the $10^{\text {th }}, 11^{\text {th }}, 12^{\text {th }}$ sessions consecutively. Training sessions were 17 minutes in total. Betül's maintenance sessions were conducted two, three, and five weeks after the training sessions were completed. She performed with $100 \%$ correct responses during the maintenance sessions.

Ibrahim displayed $0 \%$ correct responses during the baseline sessions for three days consecutively. $\mathrm{He}$ completed the training phase with 14 sessions. During the 0 -second response interval session he performed with $16 \%$ accuracy whereas during the 2-second response interval sessions, $33 \%$ correct responses in the second session, 50\% correct responses in the third session and 50\% correct responses in the fourth session were recorded. During the 4-second response interval sessions, 33\% correct responses in the fifth session, $66 \%$ correct responses in the sixth session, $83 \%$ correct responses in the seventh session, and $83 \%$ correct responses in the eighth session were recorded. During the 6-second response interval sessions, he performed with $83 \%$ accuracy in the ninth, $10^{\text {th }}$ and $11^{\text {th }}$ sessions, and with $100 \%$ accuracy in the $12^{\text {th }}, 13^{\text {th }}$ and $14^{\text {th }}$ sessions. It was seen that the total length of the training sessions were 15 minutes in total.

Yavuz also performed with $0 \%$ correct response level during the three baseline sessions consecutively. He acquired the target skill within 10 training sessions. During these sessions, 0 -second response intervals were recorded as $0 \%$ correct response in the first session. During the 2 -second response interval sessions, he performed with $33 \%$ accuracy in the second, with $66 \%$ in the third, and $83 \%$ accuracy in the fourth sessions. During the 4second response interval sessions, $100 \%$ correct responses in the fifth, sixth and seventh sessions were recorded. During the 6-second response interval sessions, again 100\% correct responses in the eighth, ninth and 10th sessions were recorded consecutively. Yavuz's training sessions took 10 minutes in total. His maintenance sessions were conducted one, two and four weeks after the training sessions were completed. He performed with $100 \%$ correct response percentage during the maintenance sessions.

\section{Betül, İbrahim and Yavuz's Generalization Results on Crossing the Road Using the Pedestrian Stripes}

Since the target skill might hold risks of danger and should be taught in a safe setting, the training was conducted in a simulation material. After the participants acquired the target skill successfully, the generalization sessions were conducted in a semi-structured real environment. Due to the same reason, pre-test data was not collected for the generalization of the skill in the real environment. Post-test results of the participants can be seen in Figure 2. It can be seen that all three participants performed with $100 \%$ accuracy in the semi-structured real environment. 


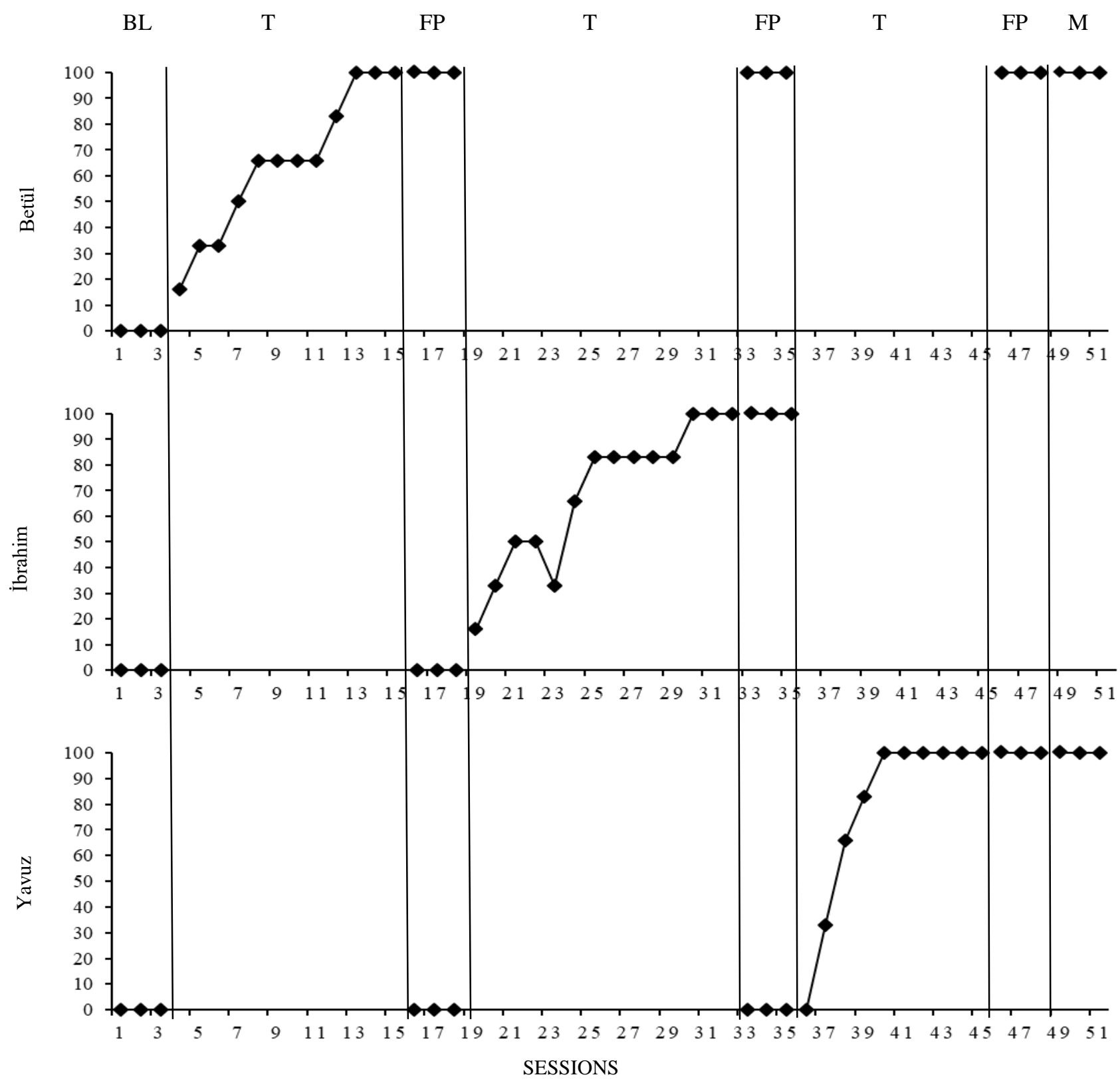

"BL: Baseline, T: Training, FP: Full Probe, M: Maintenance

Figure 1. Betül, Ibrahim and Yavuz's correct response percentages during the pedestrian skill training. 


\section{Post-test}

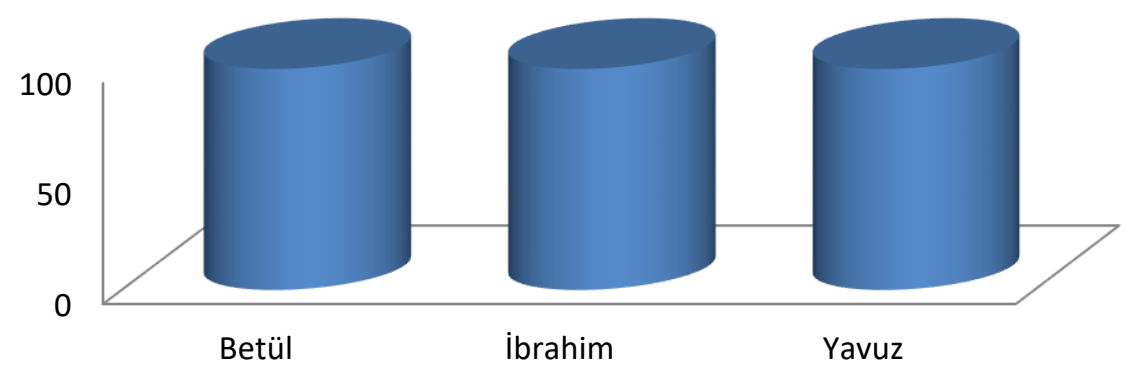

Figure 2. Betül, İbrahim and Yavuz's percentage of correct responses during post-test regarding the pedestrian skill generalization.

\section{Social Validity Results}

Social validity data were collected from the parents of the participants and the police officer who took part in the generalization sessions of the study. Question forms were prepared by the authors in order to evaluate the opinions of these people regarding the effectiveness of the study and the importance of the target skill. Questions were asked to the parents and the police officer by the first author during one-to-one interviews and their answers were voice recorded.

Social validity data collected from the parents of the participants. Parents reported that the targeted skill was really important for their children, that they were satisfied with their children's participation in the study, and that their children would have the chance to take part in the community life with the acquired skill through the study. Parents also expressed that they would be happy if their children take part in similar studies. They also mentioned that the study was conducted similar to the information provided at the beginning of the study. Parents expressed that their children told about the study they took part when they came home from school, and especially for the first and the third participants that they were very happy to learn to cross the road using the pedestrian stripes. It can be said that parents of the participants reported positive opinions regarding the study in general.

Social validity data collected from the police officer. Examining the yes/no questions, it can be said that the police officer who took part in the post-test generalization session of the study thought that the targeted skill was important for the participants to acquire. He mentioned that the participants could adapt to the community life more easily and that the participants could go to school and come back home more easily through the target skill. The police officer was asked about the positive parts of the study he was able to distinguish and extract. He replied that "it can be said that by teaching the target skill, you are conducting a very important job for the participants' social lives.".

\section{Discussion and Recommendations}

The effectiveness, maintenance and generalization of progressive time delay teaching procedure on teaching a pedestrian skill to individuals with intellectual disability was examined in the present study. Besides, social validity data were collected from the parents of the participants of the study and a police officer who took part in the post-test generalization session of the study.

Looking at the results of the present study, comparing the baseline data and the data after the training sessions were completed, it can be seen that the participants acquired the targeted skill and performed the skill steps independently. Except the second participant, other participants maintained the acquired target skill after a 
few weeks from the training sessions were conducted. Since the target skill might hold risks of danger, the pretest generalization data were not collected. However, looking at the post-test generalization data, it can also be seen that the participants managed to generalize the skill to a different setting. When the social validity data was examined, both parents' and the police officer's opinions regarding the study were positive in general.

Reviewing the national literature, there are only three studies regarding teaching pedestrian skills to individuals with intellectual disability. One of these studies was conducted at the same time period with the current study. Furthermore, there is not enough number of studies that examines the instruction of pedestrian skills as one of the basic safety skills of individuals with intellectual disability.

Examining all studies which conducted for teaching pedestrian skills in-vivo, simulation or virtual reality settings, it can be seen that the effectiveness data show consistency (Anastasia, 2010; Batu et al., 2004; Branham et al., 1999; Collins et al., 1993; Colozzi \& Pollow, 1984; Harriage et al., 2016; Hawkins, 2016; Honsberger, 2015; Josman et al., 2008; Kelley et al., 2013; Mechling \& Seid, 2011; Page et al., 1976; Tohum Otizm Vakfi, 2013; Yavuz, 2017). Since progressive time delay teaching procedure permits the generalization of target skills by means of time, using it for teaching safety skills is suggested. In the present study, effectiveness of progressive time delay was examined. The consistency of results can be seen when they are compared to the findings of previous studies (Bennett et al., 1986; Browder, Morris, \& Snell, 1981; Casey, 2008; Chen et al., 2001; Heckaman et al., 1998; Kanbaş, 2002; Leung, 1994; Reichow \& Wolery 2011; Venn \& Wolery 1992; Wolery et al., 1988).

Besides, there are some issues that should be discussed about the participants, target behavior, setting, and method of the present study. The first issue to be emphasized was that in the seven-step skill analysis was reduced to six steps following the pilot study. This was because the participants in the pilot study performed the "wait on the pavement" and "look to the side where cars are coming first" steps together. Hence the two steps were reduced to one step in the present study. Another important point to be mentioned was the first step of progressive time delay training sessions was conducted at 0 -sec delay. It stemmed from the fact that the participants walked down the pavement right after the target stimuli was provided to them. This behavior would cause danger in the real environment for them; therefore, an adaptation was made on the procedure. The third issue was that the third full probe and maintenance sessions could not be conducted with the second participant. This stemmed from the fact that the participant displayed too much problem behavior regarding the environment that could not be handled by the researchers during the study. Another issue was related to the pre-test generalization sessions. Since the target behavior was a risky skill the pre-test session was not conducted with the participants. Hence, only post-test sessions were conducted for the generalization of the target skill with the participants. Moreover, the tow cars were very attractive especially for the third participant. This turned to be a very effective reinforcer for him. Hence, his reinforcer was changed with driving the taw car during the study. One can discuss that individuals could acquire and generalize the target pedestrian skills which was one of the main components of safety skills in the community life. Furthermore, parents' wishes involving the possession of independent mobility skills and the pedestrian skill toward an independent life were realized.

In the present study; (a) the sessions were not conducted at the same time of the days because of the busy time schedules of the participants, (b) the pre-test of generalization sessions were not conducted due to the risky nature of the target skill, (c) the second participant displayed problem behaviors towards the researcher and the environment towards the end of the training sessions, (d) due to the attention of the participants in terms of batterypowered car with a third of respondents used as reinforcement as to whether the figure represents a real car, and (e) the simulation setting was sometimes noisy and this might have led to attention deficit for the participants. Such points can be listed as the limitations of the study.

It is recommended to teachers and other practitioners who work with individuals with developmental disabilities to construct simulation settings in their classes or somewhere else at schools to teach pedestrian skills. Besides, including objectives related to safety skills is recommended to the policy makers. Teachers can also prepare packages for teaching safety skills and offer them to parents. 
Some recommendations can also be presented to future researchers. Conducting the study with individuals with different levels of intellectual disabilities or individuals with autism in different conditions can be recommended (i.e. using the traffic lights, using the footbridge, crossing the road where there are no facilitators, etc.). Different teaching methods can be compared regarding their effectiveness and efficiencies on the same target skill. Preparing a family training package for teaching pedestrian skills to children with intellectual disability and examining the effectiveness of the teaching package can be recommended. 


\section{References}

Anastasia, A. (2010). Promoting road safety for preadolescent boys with mild intellectual disabilities: The effect of cognitive style and the role of attention in the identification of safe and dangerous road-crossing sites. International Journal of Special Education, 25(2), 127-135.

Bambara, L. M., Kroger, F., \& Bartholomew, A. (2014). Building skill for home and community. In M. E. Snell \& S. Brown (Eds.), Instruction of students with severe disabilities (7th ed., pp. 409-492). United States of America: Pearson New International Edition.

Barton, B. K., \& Schwebel, D. C. (2007). The roles of age, gender, inhibitory control, and parental supervision in children's pedestrian safety. Journal of Pediatric Psychology, 32(5), 517-526. doi: 10.1093/jpepsy/jsm014

Bates, P. E., Cuvo, T., Miner, C. A., \& Korabek, C. A. (2001). Simulated and community-based instruction involving persons with mild and moderate mental retardation. Research in Developmental Disabilities, 22(2), 95-115. doi: 10.1016/S0891-4222(01)00060-9

Batu, S., Ergenekon, Y., Erbas, D., \& Akmanoglu, N. (2004). Teaching pedestrian skills to individuals with developmental disabilities. Journal of Behavioral Education, 13(3), 147-164. doi: 10.1023/B:JOBE.0000037626.13530.96

Bennett, D. L., Gast, D. L., Wolery, M., \& Schuster, J. (1986). Time delay and system of least prompts: A comparison in teaching manual sign production. Education and Training of the Mentally Retarded, 21(2), 117-129.

Branham, R. S., Collins, B. C., Schuster, J. W., \& Kleinert, H. (1999). Teaching community skills to students with moderate disabilities: Comparing combined techniques of classroom simulation, videotape modeling, and community-based instruction. Education and Training in Mental Retardation and Developmental Disabilities, 34(2), 170-181.

Browder, D. M., Snell, M. E., \& Wildonger, B. A. (1988). Simulation and community-based instruction of vending machines with time delay. Education and Training in Mental Retardation, 23(3), 175-185.

Browder, D. M., Morris, W. W., \& Snell, M. E. (1981). Using time delay to teach manual signs to a severely retarded student. Education and Training of the Mentally Retarded, 16(4), 252-258.

Casey, S. D. (2008). A comparison of within-and across-session progressive time delay procedures for teaching sight words to individuals with cognitive delays. The Behavior Analyst Today, 9(3-4), 163-171. doi: $10.1037 / \mathrm{h} 0100656$

Chen, S., Zhang, J., Lange, E., Miko, P., \& Joseph, D. (2001). Progressive time delay procedure for teaching motor skills to adults with severe mental retardation. Adapted Physical Activity Quarterly, 18(1), 35-48. doi: 10.1123/apaq.18.1.35

Christensen, A. M., Lignugaris, B., Kraft, B., \& Fiechtl, B. J. (1996). Teaching pairs of preschoolers with disabilities to seek adult assistance in response to simulated injuries: Acquisition and promotion of observational learning. Education and Treatment of Children, 19(1), 3-18.

Christensen, A. M., Marchand-Martella, N. E., Martella, R. C., Fiechtl, B. J., \& Christensen, B. R. (1993). Teaching preschoolers with disabilities to seek adult assistance in response to simulated injuries. Journal of Behavioral Education, 3(2), 109-123. doi: 10.1007/BF00947031 
Cihak, D., Alberto, P. A., Taber-Doughty, T., \& Gama, R. I. (2006). A comparison of static picture prompting and video prompting simulation strategies using group instructional procedures. Focus on Autism and Other Developmental Disabilities, 21(2), 89-99. doi: 10.1177/10883576060210020601

Clees, T. J., \& Gast, D. L. (1994). Social safety skills instruction for individuals with disabilities: A sequential model. Education and Treatment of Children, 17(2), 163-184.

Collins, B. C., Stinson, D. M., \& Land, L. A. (1993). A comparison of in vivo and simulation prior to in vivo instruction in teaching generalized safety skills. Education and Training in Mental Retardation, 28(2), 128-142.

Collins, B. C., Wolery, M., \& Gast, D. L. (1992). A national survey of safety concerns for students with special needs. Journal of Developmental and Physical Disabilities, 4(3), 263-276. doi: 10.1007/BF01046968

Colozzi, G. A., \& Pollow, R. S. (1984). Teaching independent walking to mentally retarded children in a public school. Education and Training of the Mentally Retarded, 19(2), 97-101.

Dixon, D. R., Bergstrom, R., Smith, M. N., \& Tarbox, J. (2010). A review of research on procedures for teaching safety skills to persons with developmental disabilities. Research in Developmental Disabilities, 31(5), 985-994. doi: 10.1016/j.ridd.2010.03.007

Dymond, S. K., (2012). Community participation. In P. Wehman \& J. Kregel (Eds.), Functional curriculum for elementary and secondary students with special needs (3rd ed., pp. 351-387). United States of America, Texas: Pro-Ed.

Ergenekon, Y. (2012). Otizimli çocuklara videoyla model olma kullanılarak ev kazalarında basit ilkyardım becerilerinin öğretimi [Teaching basic first-aid skills against home accidents to children with autism through video modeling]. Kuram ve Uygulamada Eğitim Bilimleri, 12(4), 2739-2766.

Harriage, B., Blair, K. S. C., \& Miltenberger, R. (2016). An evaluation of a parent implemented in situ pedestrian safety skills intervention for individuals with autism. Journal of Autism and Developmental Disorders, 46(6), 2017-2027. doi: 10.1007/s10803-016-2730-8

Hawkins, T. (2016). Teaching street-crossing skills to special education students. California State University, Monterey Bay.

Heckaman, K. A., Alber, S., Hooper, S., \& Heward, W. L. (1998). A comparison of least-to-most prompts and progressive time delay on the disruptive behavior of students with autism. Journal of Behavioral Education, 8(2), 171-201. doi: 10.1023/A:1022883523915

Honsberger, T. (2015). Teaching individuals with autism spectrum disorder safe pedestrian skills using video modeling with in situ video prompting (Unpublished doctoral dissertation). Florida Atlantic University, Florida.

Jones, H., Perry, J., Lowe, K., Felce, D., Toogood, S., Dunstan, F., ... \& Pagler, J. (1999). Opportunity of the promotion of activity among adults with severe intellectual disability living in community residences: the impact of training staff in active support. Journal of Intellectual Disability Research, 43(3), 164-178. doi: 10.1046/j.1365-2788.1999.00177.x

Jones, R. T., Kazdin, A. E., and Haney, J. I. (1981). Social validation and training of emergency fire safety skills for potential injury prevention and life saving. Journal of Applied Behavior Analysis, 14(3), 249-260. doi: 10.1901/jaba.1981.14-249 
Josman, N., Ben-Chaim, H. M., Friedrich, S., \& Weiss, P. L. (2008). Effectiveness of virtual reality for teaching street-crossing skills to children and adolescents with autism. International Journal on Disability and Human Development, 7(1), 49-56. doi: 10.1515/IJDHD.2008.7.1.49

Kanbaş, E. (2002). Zihin özürlü çocuklara adı söylenen mutfak araç gereçlerine ait resmi seçme becerisinin ögretiminde artan bekleme süreli ögretimin etkililiği ve hedeflenmeyen bilgi ögretimi [The effect of progressive time delay and providing instryctive feedback on teaching receptively identifying kitchen utensil] (Yüksek lisans tezi). Anadolu Üniversitesi, Eğitim Bilimleri Enstitüsü, Eskişehir.

Kelley, K. R., Test, D. W., \& Cooke, N. L. (2013). Effects of picture prompts delivered by a video iPod on pedestrian navigation. Exceptional Children, 79(4), 459-474. doi: 10.1177/001440291307900405

Leung, J. P. (1994). Teaching spontaneous requests to children with autism using a time delay procedure with multi-component toys. Journal of Behavioral Education, 4(1), 21-31. doi: 10.1007/BF01560506

McDonnell, J. J., Horner, R. H., \& Williams, J. A. (1984). Comparison of three strategies for teaching generalized grocery purchasing to high school students with severe handicaps. Journal of the Association for Persons with Severe Handicaps, 9(2), 123-133. doi: 10.1177/154079698400900206

Mechling, L. C., \& Seid, N. H. (2011). Use of a hand-held personal digital assistant (PDA) to self-prompt pedestrian travel by young adults with moderate intellectual disabilities. Education and Training in Autism and Developmental Disabilities, 46(2), 220-237.

Nosek, M. A. (1992). Independent living. In R. M. Parker \& E. M. Szymanski (Eds.), Rehabilitation counseling: Basics and beyond (2nd ed., pp. 103-133). Texas, Austin: Pro-Ed.

Tohum Otizm Vakfı (2013). Otizimli çocukları trafikte fark ediyoruz "Bağımsızlı̆̆ıma yol verin yaya becerilerin ögretimi uygulama rehberi" [We recognize children with autism in traffic "Give way to my independence practice guide for teaching pedestrian skills”]. (Project No: TR2009/0135.01-04-169). Retrieved from https://www.tohumotizm.org.tr/wp-content/uploads/2018/06/Egitim_Rehberi_Son.pdf

Page, T. J., Iwata, B. A., \& Neef, N. A. (1976). Teaching pedestrian skill to retarded persons: Generalization from the classroom to the natural enviromental. Journal of Applied Behavior Analysis, 9(4), 433-444. doi: 10.1901/jaba.1976.9-433

Ramdoss, S., Lang, R., Fragale, C., Britt, C., O’Reilly, M., Sigafoos, J., ... \& Lancioni, G. E. (2012). Use of computer-based interventions to promote daily living skills in individuals with intellectual disabilities: A systematic review. Journal of Developmental and Physical Disabilities, 24(2), 197-215. doi: $10.1007 / \mathrm{s} 10882-011-9259-8$

Reichow, B., \& Wolery, M. (2011). Comparison of progressive prompt delay with and without instructive feedback. Journal of Applied Behavior Analysis, 44(2), 327-340. doi: 10.1901/jaba.2011.44-327

Stlington, P. L., Neubert, D. A., \& Clarck, G. M. (2010). Transition education and services for students with disabilities. United States of America: Pearson Education, Inc.

Tekin-İftar, E., \& Kırcaali-İftar, G. (2012). Özel eğitimde yanlışsız öğretim yöntemleri [Errorless teaching methods in special education]. Ankara: Vize Yayıncilık.

Test, D. W., \& Spooner, F. (2005). Community-based instructional support. In M. L. Wehmeyer \& M. Agran (Eds.), Mental reterdation and intellectual disabilities "teaching students using innovative and researchbased strategies" (pp. 79-100), American Association on Intellectual and Developmental Disabilities, United States of America: Pearson Merrill Prentice Hall. 
Venn, M. L., \& Wolery, M. (1992). Using progressive time delay in arts/crafts activities to teach peer imitation to preschoolers with disabilities. Paper presented at the Annual International Conference of the Council for Exceptional Children, Division for Early Childhood, Washington, DC.

West, M. D., Witting, K., \& Barrett, V. Z. (2012). Travel and mobility training. In P. Wehman \& J. Kregel (Eds.), Functional cirriculum for elementary and secondary students with special needs (3rd ed., pp. 333-350). United States of America, Texas: Pro-Ed.

Westling, D. L., \& Fox, L. (2000). Teaching students with severe disabilities. United States of America: PrenticeHall, Inc.

Wolery, M., Gast, D. L., Kirk, K., \& Schuster, J. (1988). Fading extra-stimulus prompts with autistic children using time delay. Education and Treatment of Children, 11(1), 29-44.

Yavuz, A. (2017). Otizm spektrum bozukluğu (OSB) olan çocuklara üst geçit kullanarak karşıdan karşıya geçme becerisinin ögretiminde videoyla model olmanın etkililiği [The effectiveness of video modelling on teaching the skill of Street- crossing using overpass to children with autism spectrum disorder] (Yüksek lisans tezi). Anadolu Üniversitesi, Eğitim Bilimleri Enstitüsü, Eskişehir.

Yeaton, W. H., \& Bailey, J. S. (1978). Teaching pedestrian safety skills to young children: An analysis and oneyear follow up. Journal of Applied Behavior Analysis, 11(3), 315-329. doi: 10.1901/jaba.1978.11-315 


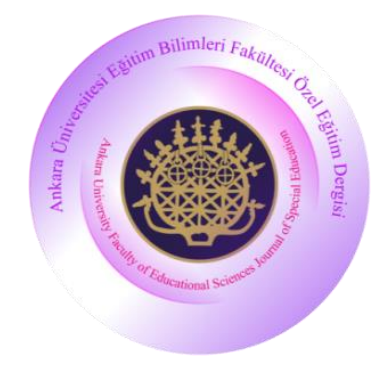

\section{Ankara Üniversitesi Eğitim Bilimleri Fakültesi Özel Eğitim Dergisi}

Yıl: 2020, Cilt: 21, Sayı: 3, Sayfa No: 427-450

doi: 10.21565/ozelegitimdergisi.597433

\section{Zihin Yetersizliği Olan Bireylere Yaya Becerilerinin Öğretiminde Artan Bekleme Süreli Öğretimin Etkililiğí"}

\author{
Kübra Ağrı \\ Anadolu Üniversitesi
}

\author{
Emine Sema Batu ${ }^{\text {iD }}{ }^{* * *}$ \\ Anadolu Üniversitesi
}

Öz

$\mathrm{Bu}$ çalışmanın amacı, zihin yetersizliği olan bireylere yaya becerilerinin öğretiminde artan bekleme süreli öğretim yönteminin etkililiğini araştırmaktır. Bununla birlikte araştırma sürecine katılan katılımcıların ailelerinden ve bir polisten seçilen becerinin işlevselliğine yönelik görüşleri alınarak çalışmanın sosyal geçerliliği belirlenmiştir. $\mathrm{Bu}$ araştırmada yaşları 10-11 arasında değişen ve hafif düzeyde zihin yetersizliği tanısı almış 3 katılımcı ile çalışılmıştır. Araştırmada tek denekli araştırma yöntemlerinden katılımcılar arası yoklama evreli çoklu yoklama modeli kullanılmıștır. Araștırmanın bulguları tüm katılımcıların yaya becerilerini kazandıklarını, birinci katılımcının uygulama bittikten 2,3 ve 5 hafta sonra, üçüncü katılımcının ise uygulama bittikten 1,2 ve 4 hafta sonra sürdürebildiklerini ve simülasyon ortamında edindikleri bu yaya becerilerini tüm katılımcıların gerçek ortama genelleyebildiğini göstermektedir. Araştırmanın sosyal geçerlilik bulguları ise araştırmaya katılan katılımcıların ailelerinin ve polisin çalışmaya yönelik görüşlerinin olumlu yönde olduğunu göstermektedir.

Anahtar sözcükler: Zihin yetersizliği, yaya becerisi, güvenlik becerisi, artan bekleme süreli öğretim yöntemi, kanıt temelli uygulamalar.

\section{Önerilen Atıf Sekli:}

Ağrı, K., \& Batu, E. S. (2020). Zihin yetersizliği olan bireylere yaya becerilerinin öğretiminde artan bekleme süreli öğretimin etkililiği. Ankara Üniversitesi Eğitim Bilimleri Fakültesi Özel Ĕ̈itim Dergisi, 21(3), 427-450. doi: 10.21565/ozelegitimdergisi.597433

\footnotetext{
*Bu çalışma Prof. Dr. Emine Sema Batu'nun danışmanlığında gerçekleştirilen Kübra Ağrı'nın yüksek lisans tezinden üretilmiştir. Ayrıca bu çalıșma Muğla'da gerçekleștirilen 2. Uluslararası Çağdaş Eğitim Araştırmaları Kongresi'nde sözlü sunu olarak (Eylül, 2017) sunulmuştur.

${ }^{* *}$ Sorumlu Yazar: Arş. Gör., E-posta: kubraagri@anadolu.edu.tr, https://orcid.org/0000-0003-1538-197X

***Prof. Dr., E-posta: esbatu@ anadolu.edu.tr, https://orcid.org/0000-0003-0770-5145
} 
Güvenlik becerileri mevcut durumda oluşabilecek sözel davranışlardan veya fiziksel istismar gibi sözel olmayan durumlardan kişinin kendini koruması, kaçması ve kaçınması olarak tanımlanabilir (Clees \& Gast, 1994). Kişisel güvenlik becerileri ise günlük yaşamda karşıdan karşıya geçme gibi temel durumlardan yabancı birisi tarafindan zorlandığında kişinin ne yapması gerektiğini bilmesi gibi daha geniş yelpazede bulunan durumlarda bireyin kendi kendine yetebilmesidir (Dixon, Bergstrom, Smith, \& Tarbox, 2010). Collins, Wolery ve Gast (1992) yaptıkları araştırmada güvenlik becerilerini ev-içi güvenlik becerileri, toplumsal güvenlik becerileri, yangından korunma, ilk yardım becerileri, yabancılardan kaçınma ve cinsel istismara karşı kendini koruma olmak üzere altı başlıkta incelemişlerdir (Collins vd., 1992). Toplumsal güvenlik becerileri altında bulunan hareket halinde olmayı gerektiren beceriler ve yolculuk yapma becerileri, bulunulan çevre içinde veya bölgeler arası hareket halinde olma olarak tanımlanabilmektedir (West, Witting, \& Barrett, 2012).

Zihin yetersizliği olan bireylere hareket halinde olmayı gerektiren becerileri kazandırmak karşıdan karşıya güvenli bir şekilde geçebilmenin ön koşuludur (Josman, Ben-Chaim, Friedrich, \& Weiss, 2008). Çocuklar açısından bakıldığında en önemli hareket halinde olmayı gerektiren aktivitelerden birisi yaya becerileridir (Yeaton \& Bailey, 1978). Bireylerin en sık kullanmak zorunda kaldığ

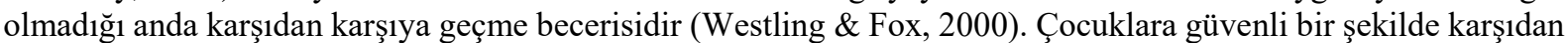
karşıya geçme becerisini öğretebilmek için trafik işaretlerinin ve anlamlarının ne olduğu, her iki yönden gelen arabaların uzaklıklarını ve hızlarını kestirme, arabanın hızına bağlı olarak karşıdan karşıya geçebilmek için yol mesafesinin nasıl olması gerektiği öğretilmelidir (Barton \& Schwebel, 2007). Güvenli olarak karşıdan karşıya geçebilmenin öğretilebilmesi için farklı türlerdeki kavşaklar kullanılması ve bu becerilerin \%100 doğrulukta gerçekleştirilmesi gerekmektedir (Westling \& Fox, 2000).

Zihin yetersizliği olan bireylere farklı öğretim yöntemleri kullanılarak ve farklı alanlar kullanılarak yaya becerisi kazandırılabilmektedir. Bu araştırmada ise zihin yetersizliği olan bireylere kazandırılması gereken önemli güvenlik becerilerinden olan yaya becerisinin öğretiminde artan bekleme süreli öğretim yöntemi kullanılmıştır. Artan bekleme süreli öğretim yöntemi ipucu türü ve yoğunluğunda değişiklik yapmadan öğretilen becerinin zaman bağlamında yavaş yavaş silikleştirilmesine firsat veren bir yöntemdir (Tekin-İftar \& Kırcaali-İftar, 2012).

Araştırmanın amacı zihin yetersizliği olan bireylerde yaya becerilerinin öğretiminde artan bekleme süreli öğretimin etkililiğini araştırmaktır. Bu amaçla araştırmaya ilişkin aşağıdaki sorulara yanıt aranmaktadır:

1. Artan bekleme süreli öğretim zihin yetersizliği olan bireylere yaya becerilerinin kazandırılmasında etkili midir?

2. Zihin yetersizliği bulunan bireyler öğrendikleri bu beceriyi öğretim sona erdikten 1,2 ve 4 hafta sonra sürdürebilirler mi?

3. Zihin yetersizliği olan bireyler öğrendikleri bu beceriyi farklı ortam ve araçlara genelleyebilirler mi?

4. Zihin yetersizliği olan bireylere bu becerinin öğretimine yönelik ailelerin ve Trafik Uygulama ve Denetleme Dairesi Başkanlığı'ndan eğitim sürecine katılan polisin görüşleri nelerdir?

\section{Yöntem}

\section{Katılımcılar}

Araştırmanın katılımcıları uygulamacı, pilot çalışma kapsamındaki bir öğrenci, uygulama öğrencileri, öğrencilerin aileleri ve bir polisten oluşmaktadır. Araştırmada, çalışmanın uygulama sürecinde zihin yetersizliği olan üç birey ile çalışılmıştır.

Betül 11 yaşında, hafif düzeyde zihin yetersizliği tanısı almış, Milli Eğitime bağlı bir ilkokulda kaynaştırma öğrencisi olarak dördüncü sınıfa devam eden bir öğrencidir. İbrahim 10 yaşında hafif düzeyde zihin yetersizliği tanısı almış, Milli Eğitime bağlı bir ilkokulda özel eğitim sınıfında dördüncü sınıfa devam eden bir 
öğrencidir. Yavuz 11 yaşında hafif düzeyde zihin yetersizliği tanısı almış, Milli Eğitim Bakanlığına bağlı bir ilkokulda özel eğitim sınıfına devam eden bir öğrencidir.

\section{Ortam ve Araç-Gereçler}

Araştırmanın başlama düzeyi, toplu yoklama, uygulama ve izleme oturumları Eskişehir Anadolu Üniversitesi Eğitim Fakültesi’nde hazırlanan benzetim (simülasyon) ortamında gerçekleştirilmiştir. Benzetim ortamında; yolun ortasında bir refüj ile ikili yol, yolun iki tarafında kaldırım, iki akülü araba, yaya geçidi, yaya geçidi işaret levhasını içeren bir ortam hazırlanmıştır. Genelleme oturumları Eskişehir Batıkent semtinde belirlenen yolda gerçekleştirilmiştir. Araştırmada Aile Katılım Onay Formu, Pekiştireç Belirleme Formu, Beceri Analizi Formu, Veri Kayıt Çizelgesi, Uygulama Güvenirliği ve Gözlemciler Arası Güvenirlik Veri Kayıt Formu, Aile Sosyal Geçerlilik Veri Kayıt Formu, Polis Sosyal Geçerlilik Formu kullanılmıştır.

\section{Araștırma Modeli}

Araştırmada yaya becerisinin öğretiminde artan bekleme süreli öğretimin etkililiği tek denekli araştırma yöntemlerinden katılımcılar arası yoklama evreli çoklu yoklama modeli kullanılarak değerlendirilmiştir.

\section{Bağımlı ve Bağımsız Değişken}

Araştırmanın bağımlı değişkeni yaya becerisinin kazandırılmasında doğru davranış yüzdesidir. Araştırmanın bağımsız değişkeni, yaya becerilerinin öğretiminde artan bekleme süreli öğretimdir.

\section{Uygulama Süreci}

Uygulama süreci; pilot çalışma, başlama düzeyi, toplu yoklama, öğretim, izleme ve genelleme oturumlarından oluşmaktadır. Tüm oturumlar bire-bir öğretim oturumu şeklinde gerçekleştirilmiştir.

Başlama düzeyi oturumları. Araştırmanın başlama düzeyi oturumları çalışma kapsamında belirlenmiş olan üç katılımcıyla ayrı ayrı gerçekleş̧irilmiş̧ir. Başlama düzeyi verileri tekli firsat yöntemine göre toplanmıştır. Beceri analizi basamaklarını gerçekleştirmesi için bireye hedef uyaran sunulmuştur (“... karşıdan karşıya geç”). Katılımonın beceri analizindeki basamaklarda yanlış yaptığı basamaktan itibaren (-) olarak işaretleme yapılmıştır fakat katılımcının devam etmesine firsat verilmiştir ve son basamakla birlikte değerlendirme sonlandırılmış̧ır. Katılımcıya herhangi bir ipucu ya da pekiştireç sunulmadan başlama düzeyi verileri toplanmıştır. Elde edilen verilere göre doğru tepki yüzdesi hesaplanmıştır.

Toplu yoklama oturumları. Araştırmanın modeli gereği her katılımcıyla üç toplu yoklama oturumu gerçekleştirilmiştir. Toplu yoklama oturumları başlama düzeyi oturumlarına benzer şekilde gerçekleştirilmiştir.

Öğretim oturumları. Öğretim oturumları, sıfir saniyeli ve artan bekleme süreli öğretim oturumları (2, 4, $6 \mathrm{sn}$ ) olarak hafta içi iki gün birer oturum ve hafta sonu iki gün 3 oturum şeklinde gerçekleştirilmiştir.

Sıfir saniye bekleme süreli öğretim oturumları. Sıfır saniye bekleme süreli öğretim uygulamasına başlamadan önce katılımcının çalışma alanında beklemesi sağlanmıştır. Çalışmaya başlarken katılımcının çalışmaya dikkati toplandıktan sonra “... bugün seninle karşıdan karşıya geçmeye çalışacağız. Benimle güzel bir şekilde çalışırsan (çalışma süresince dikkatini uygulamaya ve uygulamacıya vermek, uygulamayı gerçekleştirmek) ... (belirlenen pekiştireç sunularak - ilk iki katılımcı için çizgi film, son katılımcı için de alandaki arabaları kullanma) yapabiliriz" denilmiştir. "Şimdi hazırsan başlayalım." dendikten ve katılımıının da hazır olduğuna dair vermiş olduğu tepki ile çalışmaya başlanmıştır. Katılımcıya "karşıdan karşıya geç" hedef uyaranı sunulmuştur. Ardından kontrol edici ipucu olan kısmi fiziksel ipucu, model olma ve sözel ipucu kullanılarak "önce kaldırımda bekliyoruz ve arabanın geldiği yöne doğru önce sola, sonra sağa ve tekrar sola doğru bakıyoruz” denilerek basamak gerçekleştirilmiştir ve katılımcının da belirlenen yanıt aralığı içinde (3 saniye) davranışı gerçekleştirmesi beklenmiştir. Ardından ikinci basamağa geçilmiştir. 
Beceri analizindeki ikinci basamak için katılımcıya araba ve yol gösterilerek "araba uzakta, gelmediği için karşıdan karşıya geçebiliriz” denilmiştir. Katılımcının kolunun üst kısmından tutarak ve birlikte adım atılması sağlanarak fiziksel ipucu kullanılarak karşıdan karşıya geçmesi için kontrol edici ipuçları sunulmuştur. Katılımcının koluna fiziksel ipucu kullanılarak karşıdan karşıya geçmesi için kontrol edici ipuçları sunulmuştur. Katılımcı belirlenen yanıt aralığı içerisinde (3 sn) davranışı gerçekleştiremediği takdirde, kontrol edici ipucu sunularak katılımcının davranışı gerçekleştirmesi sağlanmıştır. Katılımcının doğru tepki göstermesiyle karşıdan karşıya geçilmiştir. Beceri analizinin üçüncü basamağı olan "karşı refüje gelir ve bekler" basamağı için katılımcıya "evet geldik ve bekliyoruz" denilerek sözel ipucu ve model olma kontrol edici ipucuyla birlikte katılımcının kolundan tutularak kendisine fiziksel yardımda bulunulmuştur.

Dördüncü basamak olan "arabaların geldiği yöne doğru önce sağa, sonra sola ve tekrar sağa doğru bakar" basamağı için katılımcıya "evet şimdi arabaların geldiği yöne doğru önce sağa, sonra sola ve tekrar sağa doğru bakıyoruz" denilerek ve kontrol edici ipuçları kullanılarak katılımcının uygun yöne bakması sağlanmıştır. Katılımcı da eşzamanlı olarak uygulamacı ile davranışı gerçekleştirmiştir. Beşinci basamak olan "arabaların gelmediğinden veya uzakta olduğundan emin olduktan sonra yaya geçidini kullanarak seri şekilde karşıdan karşıya geçer” basamağı için “arabamız uzakta olduğu için karşıdan karşıya geçebiliriz” denilerek, yaya geçidi gösterilerek ve kontrol edici ipucu sunularak davranışın gerçekleştirilmesi sağlanmıştır. Katılımcının karşıdan karşıya geçme davranışını gerçekleştirdikten sonra son basamak olan "kaldırıma gelir ve durur" basamağı için birlikte kaldırıma gelme ve durma davranışı eş zamanlı olarak gerçekleştirilmiştir. Bu basamak gerçekleştirildikten sonra katılımcıya "aferin çok güzel geldin ve durdun" denilmiştir ve çalışmaya katıldığı için katılımcıya "çalışmamız bitti, benimle çok güzel çalıştın, teşekkür ederim.” denilerek çalışma sonlandırılmıştır.

Artan bekleme süreli öğretim oturumları. Katılımcıya "karşıdan karşıya geç” hedef uyaranı sunulmuştur. Tüm katılımcılar hedef uyarandan sonra hemen geçme davranışını gerçekleştirmeye çalışmışlardır. Fakat becerinin doğası gereği tehlikeli bir beceri olmasından dolayı tüm artan bekleme süreli öğretim oturumlarında ilk basamak sıfır saniye şeklinde gerçekleştirilmiştir. Ardından katılımcının beceri analizinin ikinci basamağını "arabaların gelmediğinden veya uzakta olduğundan emin olduktan sonra yaya geçidini kullanarak karşıdan karşıya seri şekilde geçer" gerçekleştirmesi için 2 saniye beklenmiştir (4 ve 6 saniye bekleme süreli öğretim oturumlarına da ölçüt karşılandıkça geçilmiştir ve bu oturumlar da benzer şekilde gerçekleştirilmiştir). Bu basamak gerçekleştirildiğinde "evet harikasın araba uzakta olduğu için geçebilirsin" denilmiştir. Eğer katılımcı bu basamağı yanlış yaparsa veya tepkide bulunmazsa 2 saniye sonunda kontrol edici ipucu "arabamız uzakta gelmiyor" denilerek, arabanın geldiği yön gösterilmiş ardından yaya geçidi gösterilerek "karşıya geçebiliriz” denmiş katılımcının koluna dokunarak yanıt aralığı içinde ( $3 \mathrm{sn}$ ) katılımcının tepkide bulunması sağlanmıştır. Katılımcı doğru tepkiyi sergiledikten sonra beceri analizinin diğer basamağına geçilmiştir. Beceri analizinde yer alan diğer basamaklarda da sıfır saniye bekleme süreli öğretim oturumunda olduğu gibi aynı tür ipuçları kullanılarak gerçekleştirilmiştir. Ancak bekleme süreli öğretim oturumlarında (2-4-6 saniye) beceri analizinde yer alan diğer basamakları gerçekleştirmesi için 2-4 ve 6 saniye beklenerek basamakları gerçekleştirmesi sağlanmıştır. Öğretim oturumları \%32 ölçütünü karşılayıncaya kadar 2 saniye bekleme süreli öğretim, \%64 ölçütünü karşılayıncaya kadar 4 saniye bekleme süreli öğretim ve \%100 ölçütünü karşılayıncaya kadar 6 saniye bekleme süreli öğretim şeklinde artan bekleme süreli öğretim olarak gerçekleştirilmiştir.

Genelleme oturumları. Genelleme oturumları, beceri tehlikeli olduğundan yarı-yapılandırılmış ortamda sadece son-test olarak gerçekleştirilmiştir. Genelleme oturumları Trafik Denetleme Şube Müdürlüğü’nden alınan izinle ve Trafik Denetleme Şube Müdürlüğü’nden iki polis ile birlikte Eskişehir Batıkent Semtinde gerçek ortamda gerçekleştirilmiştir. Genelleme oturumları, başlama düzeyi oturumları gibi gerçekleştirilmiştir.

İzleme oturumları. İzleme oturumları katılımcılarla çalışma bittikten 1, 2, ve 4 hafta sonra toplanacak şekilde planlanmıştır. Fakat birinci katılımcıyla 2, 3 ve 5 hafta sonra izleme verisi toplanabilmiştir. İkinci katılımcının sergilediği problem davranışlardan dolayı izleme verisi toplanamamıştır. Üçüncü katılımcı ile 1, 2 ve 4 hafta sonra izleme verisi toplanmıştır. İzleme oturumları da başlama düzeyi oturumlarına benzer şekilde gerçekleştirilmiştir. 


\section{Verilerin Toplanması}

Araştırma süreciyle ilgili olarak üç tür güvenirlik verisi toplanmıştır. Bunlar: etkililik verisi, güvenirlik verisi ve sosyal geçerlik verisidir.

Etkililik verileri. Çalışma kapsamında etkililik verileri beceri analizi kayıt formu kullanılarak toplanmıştır. İpucundan önceki doğru tepkiler forma doğru tepki, diğer tepkiler ise yanlıs tepki olarak işaretlenmiştir. Elde edilen veriler için etkililik verisi "doğru tepki sayısı/ toplam tepki sayısı x 100" formülü ile hesaplanmıştır.

Güvenirlik verileri. Güvenirlik verisi için uygulama güvenirliği ve gözlemciler arası güvenirliği analizi yapılmıştır. Uygulama güvenirliği "Gözlenen uygulamacı davranışı// Planlanan uygulamacı davranışı X 100" formülü kullanarak hesaplanmıştır (Tekin-İftar \& Kırcaali-İftar, 2012, s. 94). Gözlemciler arası güvenirlik verisi ise "Gözlemciler arası görüș birliği/ Görüs birliği + Görüș ayrılığı x 100" formülü kullanılarak hesaplanmıștır (Tekin-İftar \& Kırcaali-İftar, 2012). Yansız atama ile seçilen her bölümde \%30’u için uygulama güvenirliği veri kayıt formuna göre uygulama güvenirliği analizi verisi toplanmıştır. Uygulama güvenirliği verileri Betül için \% $\% 9$, İbrahim için \%99 ve Yavuz için \%100 olarak hesaplanmıştır. Gözlemciler arası görüş birliği verileri ise Betül için \%85, İbrahim için \%100 ve Yavuz için \%100 olarak hesaplanmıştır.

Sosyal geçerlik verileri. Sosyal geçerlik verisi, anne babaların ve çalışmanın genelleme oturumunda yer alan polisin çalışmanın etkililiği, çalışılan becerinin önemi ve çalışma ile ilgili düşüncelerini değerlendirebilmek amacıyla evet-hayır şeklinde 6 soru ve 3 açık uçlu soru olmak üzere 9 sorudan oluşan Anne-Baba Sosyal Geçerlik Formu ailelerle yapılan görüşme ile, 4 evet/ hayır ve 2 açık uçlu sorudan oluşan Polis Sosyal Geçerlik Soru Formu ise sadece bir polis memurunun katılmayı kabul etmesi ile bir polis ile görüşülerek toplanmıştır.

\section{Bulgular} verilmektedir.

Araştırmanın bu bölümünde etkililik, kalıcılık, genelleme ve sosyal geçerlik ile ilgili bulgulara yer

\section{Etkililik Bulguları}

Betül başlama düzeyi oturumlarında üç oturum üst üste $\% 0$ doğru tepki göstermiştir. Yöntem gereği Betül ile başlama düzeyi dışında üç toplu yoklama oturumu gerçekleştirilmiştir. Betül'ün toplu yoklamalarda $\% 100$ doğru tepki göstererek beceriyi edindiği görülmektedir. Betül'ün öğretim uygulaması 12 öğretim oturumunda tamamlanmıştır. Bu oturumlarda sıfir saniye süreli birinci öğretim oturumunda doğru tepki yüzdesi \%16 olarak, iki saniye bekleme süreli öğretim oturumlarında ikinci öğretim oturumunda \%33, üçüncü öğretim oturumunda $\% 33$, dördüncü öğretim oturumunda $\% 50$ olarak bulunmuştur. Dört saniye bekleme süreli öğretim oturumunda beşinci öğretim oturumunda $\% 66$, altıncı öğretim oturumunda $\% 66$ ve yedinci öğretim oturumunda $\% 66$ olarak bulunmuştur. Altı saniye bekleme süreli öğretim oturumunda ise sekizinci öğretim oturumunda \%66, dokuzuncu öğretim oturumunda $\% 83,10$. öğretim oturumunda $\% 100,11$. öğretim oturumunda $\% 100$ ve 12 . öğretim oturumunda \%100 olarak bulunmuştur. İzleme oturumlarında Betül \%100 doğru tepkide bulunmuştur.

İbrahim başlama düzeyi oturumlarında üç oturumda üst üste $\% 0$ doğru tepki göstermiştir. İbrahim ile iki toplu yoklama oturumu gerçekleştirilmiştir. İbrahim öğretim uygulamasını 14 öğretim oturumunda tamamlamıştır. Bu oturumlarda sıfir saniye süreli birinci öğretim oturumunda doğru tepki yüzdesi $\% 16$ olarak bulunmuştur. İki saniye bekleme süreli öğretim oturumlarında ikinci öğretim oturumunda \%33, üçüncü öğretim oturumunda $\% 50$, dördüncü öğretim oturumunda $\% 50$ olarak bulunmuştur. Dört saniye bekleme süreli öğretim oturumunda beşinci ögretim oturumunda $\% 33$, altıncı öğretim oturumunda $\% 66$, yedinci öğretim oturumunda $\% 83$, sekizinci öğretim oturumu $\% 83$ olarak bulunmuştur. Altı saniye bekleme süreli öğretim oturumunda ise dokuzuncu öğretim oturumunda $\% 83$, 10. öğretim oturumunda $\% 83,11$. öğetim oturumunda $\% 83,12$. öğretim oturumunda $\% 100$, 13. öğretim oturumunda $\% 100$ ve 14 . öğretim oturumunda $\% 100$ olarak bulunmuştur. İbrahim'in öğretim uygulamasında üç oturum \%100 doğru tepkide bulunarak beceriyi edindiği görülmektedir. 
Yavuz ile başlama düzeyi oturumları ile birlikte üç toplu yoklama oturumu gerçekleştirilmiştir. Yavuz öğretim uygulamasını 10 öğretim oturumunda tamamlamıştır. Bu oturumlarda sıfır saniye süreli birinci öğretim oturumunda doğru tepki yüzdesi \%0 olarak bulunmuştur. İki saniye bekleme süreli öğretim oturumlarında ikinci öğretim oturumunda $\% 33$, üçüncü öğretim oturumunda $\% 66$, dördüncü öğretim oturumunda $\% 83$ olarak bulunmuştur. Dört saniye bekleme süreli öğretim oturumunda beşinci öğretim oturumunda \%100, altıncı öğretim oturumunda $\% 100$ ve yedinci öğretim oturumunda \%100 olarak bulunmuştur. Altı saniye bekleme süreli öğretim oturumunda ise sekizinci öğretim oturumunda $\% 100$, dokuzuncu öğretim oturumunda \%100, 10. öğretim oturumunda \%100 olarak bulunmuştur. Yavuz’un öğretim uygulamasında üç oturum \%100 doğru tepkide bulunarak beceriyi edindiği görülmektedir. Gerçekleştirilen izleme oturumlarında Yavuz \%100 doğru tepkide bulunmuştur.

\section{Betül, İbrahim ve Yavuz'un Yaya Geçidinden Karşıdan Karşıya Geçme Becerisine İlişkin Genelleme Bulguları}

Çalışmanın genelleme oturumu yarı-yapılandırılmış gerçek ortamda gerçekleştirilmiştir. Genelleme oturumlarında Betül'ün \% 100, İbrahim'in \%100 ve Yavuz'un da \% 100 olarak doğru tepki verdiği görülmüştür.

\section{Sosyal Geçerlik Bulguları}

Araştırmada artan bekleme süreli öğretim kullanılarak benzetim ortamında yaya becerisinin öğretimine yönelik katılımcıların ailelerinden ve genelleme son-test sürecine katılan polis memurundan hedeflenen beceri ve becerinin önemi ile ilgili sosyal geçerlik verisi toplanmıştır.

Aileler öğretilen becerinin önemli olduğu, çocuklarının çalışmaya katılmasından memnun kaldıkları, öğretilen beceri ile çocuklarının toplumsal yaşama uyum sağlayabilecekleri yönünde olumlu görüş bildirmişlerdir. Ayrıca, çocuklarının buna benzer başka çalışmalara da katılmasını istediklerini, çalışmanın daha önceden de verilen bilgilendirmeye bağlı kalınarak yürütüldüğünü ifade etmişlerdir.

Formda yer alan kapalı uçlu sorulara bakıldığında, genel olarak polis memurunun çalışmada seçilen becerinin önemli olduğunu ve becerinin öğretilmesinin öğrenci açısından önemli olduğunu düşündüğü görülmektedir. Ayrıca polis memuru yaya becerisinin kazandırılması ile bireylerin toplumsal yaşama daha uyumlu katılabileceğini ve son olarak da bu beceriyi kazanmış olan bireylerin okula gidiş ve gelişlerinin kolaylaşacağını düşündüğ̈üü ifade etmiştir.

\section{Tartışma ve Öneriler}

Araştırma sonucunda elde edilen bulgulara, bakıldığında çalışmaya katılan tüm katılımcıların yaya geçidinden karşıdan karşıya geçme becerisini edindikleri, ikinci katılımcı dışında diğer katılımcıların öğretim oturumları tamamlandıktan birkaç hafta sonra da edindikleri bu beceriyi sürdürebildikleri, genelleme son-test oturumuna göre bu beceriyi farklı ortama genelleyebildikleri görülmektedir. Araştırmadan elde edilen sosyal geçerlik bulgularına bakıldığında ise araştırmaya katılan zihin yetersizliği olan katılımcıların ailelerinin ve polis memurunun çalışma ile ilgili görüşlerinin olumlu yönde olduğu görülmektedir.

Araştırma bulgularına bakıldığında, zihin yetersizliği olan bireylerin yaya becerisini edindikleri görülmektedir. Gerçekleştirilen bu çalışma alanyazındaki doğal ortamda, benzetim ortamında ve sanal gerçeklik kullanılarak gerçekleştirilen diğer çalışmalarla değerlendirildiğinde ise yaya becerisinin öğretimine yönelik çalışmaların etkililik sonuçlarıyla tutarlılık göstermektedir (Anastasia, 2010; Batu, Ergenekon, Erbaş, \& Akmanoglu, 2004; Branham, Collins, Schuster, \& Kleinert, 1999; Collins, Stinson, \& Land, 1993; Colozzi \& Pollow, 1984; Harriage, Blair, \& Miltenberger, 2016; Hawkins, 2016; Honsberger, 2015; Josman vd., 2008; Kelley, Test, \& Cooke, 2013; Mechling \& Seid, 2011; Page, Iwata, \& Neef, 1976; Tohum Otizm Vakfi, 2013; Yavuz, 2017). Bununla birlikte bu çalışmada yaya becerisinin öğretiminde artan bekleme süreli öğretim yönteminin etkililiği sınanmıştır. Çalışmanın bulguları yöntemin etkili olduğunu göstermektedir. Alanyazında artan bekleme süreli öğretim yöntemi ile ilgili yapılmış olan çalışmalarla karşılaştırıldığında sonuçların tutarlılık 
gösterdiği görülmektedir (Bennett, Gast, Wolery, \& Schuster, 1986; Browder, Morris, \& Snell, 1981; Casey, 2008; Chen, Zhang, Lange, Miko, \& Joseph, 2001; Heckaman, Heckaman, Alber, Hooper, \& Heward, 1998; Kanbaş, 2002; Leung, 1994; Reichow \& Wolery 2011; Venn \& Wolery 1992; Wolery, Gast, Kirk, \& Schuster, 1988).

Yukarıda belirtilen noktaların yanı sıra, tartışılması gereken noktalardan ilki, pilot çalışma sonucunda belirlenen 7 basamaktan oluşan beceri analizi basamaklarının ilk katılımcı ile çalışmaya başlandıktan sonra 6 basamak olarak değiştirilmesidir. Çalışmanın üzerinde durulması gereken ikinci noktası ise becerinin edinim sürecinde tüm artan bekleme süreli öğretim oturumlarında beceri analizinin ilk basamağının sıfir saniye olarak gerçekleştirilmesidir. Üçüncü bir nokta ise, ikinci katılımcı ile üçüncü toplu yoklama oturumlarının ve izleme oturumlarının gerçekleştirilememesidir. Tartışılması gereken son nokta ise tüm katılımcılarla genelleme ön-test oturumunun gerçekleştirilmemiş olmasıdır.

Araştırma süreci ve ortam ile ilgili tartışılması gereken noktalardan ilki; katılımcıların okul ve özel bir özel eğitim ve rehabilitasyon merkezine devam etmelerinden dolayı çalışma günleri ile ilgili yaşanan belirsizliktir. Çalışmada sistematik olarak belli bir gün belirlenip oturumlar gerçekleştirilememiş olsa da katılımcıların bu beceriyi başarılla gerçekleştirdiği görülmektedir. Diğer bir konu ise ortamda araba olarak kullanılan akülü arabaların özellikle üçüncü katılımcının oldukça dikkatini çekiyor olmasıdır. Bu durum da üçüncü katılımcı için pekiştireç olarak kullanılmasının katılımcı için gerçek araba figürünü temsil edip etmediği tartışılabilir.

$\mathrm{Bu}$ araştırmada a) oturum saatlerinin katılımcılara göre belirlenmesinden dolayı belli bir saatte gerçekleştirilememiş olması, b) yaya becerisinin içinde barındırdığı olası tehlike durumundan dolayı araştırmada genelleme ön-test oturumunun gerçekleştirilememiş olması, sadece son test oturumlarının gerçekleştirilmiş olması ve gerçek ortamdaki performanslarının öğretim öncesi değerlendirilememiş olması, c) araştırma sürecinde öğretim sürecinin sonuna doğru ikinci katılımcının ortama ve uygulamacıya dair problem davranış sergilemesi, d) üçüncü katılımcı ile akülü arabaların dikkatini çekmesinden dolayı pekiştireç olarak kullanılmasının katılımcı açısından gerçek bir araba figürü temsil edip etmediği, e) araştırmanın gerçekleştirilmesinde hazırlanan ortamda bazen fazla ses olması ve bu durumun katılımcıların dikkatini dağıtıyor olması araştırmanın sınırlılıklarını oluşturmaktadır.

Gerçekleştirilen bu araştırmanın bulgularına göre alanda çalışan öğretmenlere, tüm yetersizlik grubundaki bireylerle yaya becerilerin kazandırılması için sınıf ortamında da benzer simülasyon ortamı oluşturularak yaya becerilerinin kazandırılması için öneride bulunulabilir. Bununla birlikte müfredatta güvenlik becerilerinin uygulamalı olarak gerçekleştirilmesi için amaçlar yerleştirilebilir. Öğretmenler ve diğer uygulamacılar bireyler açısından riskli olabilecek farklı beceriler için (farklı alanlarda yaya becerisinin öğretimi, bankamatikten para çekme, vb.) benzetim ortamı hazırlayarak öğretim gerçekleştirebilirler. Öğretmenler bu beceriye yönelik ailelere bir öğretim paketi hazırlayabilirler ve bu paketlerin nasıl uygulanacağına ilişkin ailelerle öğretim gerçekleştirilebilir. Bununla birlikte alanda çalışan araştırmacılar ise; araştırmayı farklı düzeyde zihin yetersizliği bulunan ve OSB'li bireylerle gerçekleştirilmesi önerilebilir. Farklı öğretim oturumlarının kullanılarak ve farklı ortamlarda (1şıklı ortamda yaya geçidini kullanarak karşıdan karşıya geçme, üst geçidi kullanarak karşıdan karşıya geçme, yaya geçidi olmayan ortamda karşıdan karşıya geçme) öğretimin gerçekleştirilmesi ve tüm oturumların gerçek ortamda gerçekleştirileceği çalışmanın gerçekleştirilmesi önerilebilir. Yaya becerisinin kazandırılmasında ailelerin çocuklarına bu beceriyi kazandırması için aile öğretim paketi hazırlanacağı araştırmalar desenlendiği ve yaya becerisinin kazandırılmasında akran öğretiminin etkililiğini değerlendirileceği araştırmalar desenleyebilirler. 